DOI: $10.14746 /$ r.2020.2.9

\title{
Daria ZADROŻNIAK
}

Uniwersytet im. Adama Mickiewicza w Poznaniu

ORCID: 0000-0001-5068-1893

\section{Przemiany narodowo-rasowe w kulturze popularnej na przykładzie kina amerykańskiego}

\begin{abstract}
Streszczenie: Zniesienie segregacji rasowej w prawie amerykańskim nastąpiło w latach 60. XX wieku, jednak wciąż można wskazać jej skutki w przestrzeni publicznej. Wiąże się to ze stereotypami i dyskryminacją mniejszości na tle narodowo-rasowym. Obecne są one także w kinematografii poprzez m.in. dysproporcje w zakresie przyznawania ról, sposób ukazywania osób, a także takie zjawiska jak whitewashing czy blackface minstrels. Celem artykułu jest wskazanie przemian, które zachodziły na tym tle w ostatnim wieku. Próbę badawczą stanowiło 85 produkcji wyróżnionych Nagrodą Amerykańskiej Akademii Filmowej w kategorii „najlepszy film”. Przeprowadzona analiza wykazała, że w historii kina amerykańskiego można wskazać momenty przełomowe w zakresie przemian narodowo-rasowych oraz ujęła wspomniane zjawiska.
\end{abstract}

Słowa kluczowe: Stany Zjednoczone, kino, rasa, narodowość, kultura

\section{Wstęp}

W'śód współczesnych problemów społecznych poruszanych przez opinię publiczną można wskazać nierówności narodowo-rasowe. Szczególnie są one zauważalne w Stanach Zjednoczonych, a genezy podziałów na tym tle należy doszukiwać się m.in. w obowiązującym w systemie niewolnictwa (do 1865 roku) oraz segregacji rasowej (do lat 1964-1965) (Weisberger, 1995, s. 55; Graham, 1995, s. 94). W historii tego państwa można odnotować wydarzenia, które pogłębiały konflikty narodowo-rasowe, np. wojna z plemionami indiańskimi w latach 20. i 30. oraz 60. XIX wieku czy działalność organizacji terrorystycznych, takich jak Ku Klux Klan (Jenkins, 2009, s. 132-133; Weisberger, 1995, s. 86), a także takich zjawisk jak brutalność ze strony policji i masowa inkarceracja. Dowodem na to, że w społeczeństwie amerykańskim wciąż mają miejsce nierówności na tym tle mogą być m.in. protesty w bieżącym, 
2020 roku stanowiące reakcję na śmierć George'a Floyda ${ }^{1}$. Utożsamiane są one z ruchem Black Live Matters ${ }^{2}$, który walczy o prawa osób należących do mniejszości rasowych (Black Live Matter, 2020).

Wyniki licznych dociekań naukowych pokazały, że także w amerykańskich produkcjach filmowych wciąż istnieją znaczne dysproporcje w zatrudnianiu aktorów o białym kolorze skóry oraz przedstawicieli mniejszości rasowych, narodowych i etnicznych (Pancewicz, 2011; Smith, Choueiti, Pieper, 2013). Odpowiedzią na nierówności w tym środowisku oraz wynikające $\mathrm{z}$ nich protesty artystów, osób powszechnie znanych oraz samych widzów (Grossman, 2015) są ogłoszone we wrześniu 2020 roku zmiany w regulaminie Amerykańskiej Akademii Filmowej. Związane są one z sytuacją kobiet, osób z niepełnosprawnościami, mniejszości seksualnych, ale także narodowo-rasowych. Tym samym od 2025 roku, aby produkcja mogła zostać wyróżniona statuetką w kategorii „,najlepszy film" musi spełnić dwa z czterech standardów, wśród których znajdują się aktorzy, podejmowana tematyka i narracja, zespół filmowy, dostęp do branży i możliwości rozwoju oraz komunikacja $\mathrm{z}$ widownią. W tych grupach mają znaleźć się osoby reprezentujące wspomniane wcześniej mniejszości (Oscars..., 2020) Należy podkreślić, że zaproponowane przez Akademię zmiany zostały uznane przez część odbiorców za kontrowersyjne. Ich zdaniem nagroda powinna być przyznana „najlepszemu” filmowi. Tym samym to „zasługi” powinny być wyznacznikiem, a nie narzucone standardy dotyczące równości (The Academy, 2020).

Celem niniejszego artykułu jest analiza zawartości 85 produkcji filmowych wyróżnionych Nagrodą Amerykańskiej Akademii Filmowej w kategorii „najlepszy film”. Nagroda ta - jak wskazuje Marek Hendrykowski - uznawana jest za najbardziej prestiżowe wyróżnienie w tej dziedzinie, ze względu na 92-letnią tradycję jej przyznawania (Hendrykowski, 1988, s. 9). Przeprowadzone badanie dotyczyło sposobu ukazywania

${ }^{1}$ George Floyd zmarł 25 maja 2020 w wyniku aresztowania. Wydarzenie przyczyniło się do fali protestów na tle rasowym, przez wzgląd na kolor skóry policjantów („,biały”) oraz poszkodowanego (,czarny”). Kontrowersje stanowi sposób zatrzymania i moment trzymania przez funkcjonariusza kolana na szyi aresztowanego oraz zarejestrowane przez monitoring słowa „nie mogę oddychać”, które stały się hasłem protestujących (Jimenez, Chavez, Hanna, 2020).

${ }^{2}$ Międzynarodowa organizacja została założona w 2013 roku. Przyczynę jej powstania stanowił wyrok sądu, który uniewinnił osobę odpowiedzialną za śmierć Trayvona Martina. Celem jej działań jest walka z rasizmem, który dotyka społeczność czarnoskórą, wśród nich można wskazać protesty w 2020 roku w wielu państwach, głównie w Stanach Zjednoczonych (Black Live Matter, 2020). 
Przemiany narodowo-rasowe w kulturze popularnej na przykładzie kina...

mniejszości narodowo-rasowych i etnicznych oraz sposobu przyznawania ról filmowych aktorom reprezentującym owe mniejszości. Metodologia badania została zaprezentowana $\mathrm{w}$ jednym $\mathrm{z}$ podrozdziałów niniejszego artykułu. Na jego potrzeby sformułowano pytania badawcze - W jaki sposób przemiany narodowo-rasowe wpłynęły na kino amerykańskie? Jakie zjawiska dotyczące ukazywania postaci zaprezentowano w analizowanych produkcjach? Czy i w jaki sposób zaprezentowano obowiązujące w prawie amerykańskim systemy np. niewolnictwa lub segregacji rasowej? Tym samym hipoteza badawcza stanowi, że wydarzenia historyczne o znaczeniu narodowo-rasowym w Stanach Zjednoczonych mają wpływ na przemiany zachodzące $\mathrm{w}$ przemyśle filmowym $\mathrm{w}$ postaci m.in. polityki obsadzania ról.

\section{Stereotypy a nacjonalizm i etnocentryzm}

W kontekście kształtowania wizerunku mniejszości narodowo-rasowych istotną rolę odgrywają stereotypy. Elliot Aronson, Timothy D. Wilson i Robin M. Akert definiują ten termin jako „generalizację odnoszącą się do grupy, w ramach której identyczne charakterystyki zostają przypisane wszystkim bez wyjątku jej członkom, niezależnie od rzeczywistych różnic między nimi" (Aronson, Wilson, Akert, 1997, s. 542-543). Stereotyp stanowi jeden z komponentów postawy określanej jako uprzedzenie. Dotyczy kwestii poznawczej, a więc sposobu myślenia. W szczególności odnosi się on do takich aspektów jak płeć, orientacja seksualna, niepełnosprawność, ale także narodowość czy kolor skóry. Skutkiem uproszczeń rzeczywistości może być negatywne lub wręcz wrogie działanie względem przedstawicieli grupy obcej.

Warto także wskazać na dwa inne pojęcia, które wpływają na zachowanie przedstawicieli jednej grupy względem innej, a są silnie związane z problematyką narodowo-rasową, a mianowicie etnocentryzm i nacjonalizm. Pierwszy z nich odnosi się do sposobu postrzegania innej kultury. Aleksandra Jasińska-Kania i Krystyna Skarżyńska ujmują ten termin jako „przyjmowanie kultury własnej grupy za podstawę opisu i ocen innych grup. Łączy się to z niezdolnością do zrozumienia sensu, jakie nadają one zachowaniom w ramach swojej kultury" (Jasińska-Kania, Skarżyńska, 2001, s. 120). Wiąże się to z uznaniem swojej kultury postrzeganej subiektywnie, jako „lepszej”, a także przedkładanie wartości i norm obowiązujących w niej jako jedynych właściwych. Może to prowadzić 
to lekceważenia przekonań i obowiązujących zasad w stosunku do grup reprezentujących inne kultury.

Drugie z pojęć, tj. nacjonalizm odnosi się do różnic między narodami (Baldwin i in., 2007, s. 194). Wskazuje się na dwie odmiany tego pojęcia - pozytywną i negatywną, wynikających z przyjmowanych postaw. Pierwsza łączy się z pojęciem patriotyzmu, utożsamianego z więzią emocjonalną względem ojczyzny. Wynika z niej gotowość do poświęceń, np. walki o jej niepodległość (Wojtaszak, 2015). Natomiast druga odmiana - negatywna rozumiana jest jako „ideologia zakładająca, że więzi narodowe są najważniejsze dla jednostki i społeczeństwa, że mają one charakter przymusu i powinności moralnej, a lojalność narodowa powinna wyłączać wszelkie inne rodzaje więzi, ponieważ ta pierwsza stanowi jedyną prawomocną podstawę władzy i państwa, własny naród zaś z natury jest lepszy od innych" (Wojciszke, 2017, s. 120). Taki sposób postrzegania rzeczywistości może prowadzić do szowinizmu, w którym miłość do ojczyzny łączy się z wrogością wobec innych nacji (Kossecki, 2015, s. 5).

\section{Znaczenie społeczno-kulturowe kina}

Kino, jak inne masowe środki przekazu pośredniczy między nadawcą a odbiorcą, tym samym pełniąc funkcje o charakterze społeczno-kulturowym. Wśród nich można wskazać m.in. informacyjną, rozrywkową, wychowawczą, perswazyjną, ideologiczną oraz artystyczną. Na pierwszą z wymienionych wskazywał już w 1898 roku jeden z pionierów kina - Bolesław Matuszewski. Podkreślał on, iż „kinematograf nie ukazuje, być może, historii w jej pełnym kształcie, to jednak, co ukazuje, jest niewątpliwe i stanowi absolutną prawdę. [...] Zwykła taśma celuloidowa, naświetlona, stanowi nie tylko dokument historyczny, lecz także cząstkę historii" (za: Płażewski, 2007, s. 11). Jednocześnie kino stanowi także źródło rozrywki oraz dostarcza emocji. Marek Krajewski wskazuje, iż taka forma spędzania czasu wiąże się z otwartością i wieloznacznością ze strony widzów. Tym samym grupa odbiorców jest zróżnicowana pod względem takich kryteriów jak m.in. wiek, płeć, czy wykształcenie, co wpływa na popularność tego rodzaju przekazów (Krajewski, 2005, s. 35-36). Kino ma za zadanie także integrować. Podkreśla to w swojej publikacji Rick Altman, uzasadniając pewnym zaangażowaniem się widzów, którzy w wyniku zainteresowania tym samym gatunkiem filmowym tworzą wspólnotę. W szczególnych sytu- 
acjach konkretna produkcja może wytworzyć podobne więzi między jej fanami (Altman, 2012, s. 372).

O znaczeniu kolejnej z funkcji, tj. wychowawczej, świadczą pokazy filmów w szkołach czy organizowanie wycieczek do kina na produkcje uznawane za „wartościowe”. Wśród nich można wskazać m.in. ekranizacje omawianych lektur czy te prezentujące wydarzenia historyczne. Należy podkreślić, że w przypadku tej funkcji można wskazać także te produkcje, które społecznie odbierane są jako „szkodliwe” czy „kontrowersyjne", z których powodu dochodziło w przeszłości do odmowy emisji w kinach, a nawet próby ocenzurowania. Przykład takiego filmu stanowi „Kod da Vinci” (Piątek, 2006). Kino może pełnić także rolę propagandową, na co wskazuje Witold Adamczyk. Wiąże się to z wykorzystywaniem przez twórców odpowiednio dobranych słów i symboli w filmie w celu wywołania konkretnych skojarzeń i emocji. Ma to szczególne znaczenie zwłaszcza w przypadku osób młodych, gdyż przejawia się to na takich płaszczyznach jak wiedza, plany życiowe, marzenia, ideały itd. (Adamczyk, 2005). W przypadku kina można także wskazać funkcję perswazyjną, wykorzystywaną np. do celów marketingowych.

Należy zaznaczyć, iż kino jest również nośnikiem idei. Twórcy także byli i nadal są ludźmi, żyjącymi w określonej społeczności, w której podnoszone są ważne dla nich kwestie. Stąd też, jak zaznacza Dagmara Rode (2014, s. 110-111), środki przekazu stanowią ważne narzędzie informowania społeczeństwa przez różne środowiska, np. feministyczne. Wyrazem tego może być coraz częstsze prezentowanie silnych postaci kobiecych w produkcjach filmowych np. „Wonder Woman”, czy „Gwiezdne Wojny. Skywalker. Odrodzenie” (Wonder..., 2017; Gwiezdne..., 2019). Kino postrzegane jest także w kategoriach sztuki, stąd określenie „X muzy”. Od momentu powstania tego medium wskazywało się na bliskość z takimi dziedzinami jak malarstwo czy muzyka. Dlatego też w produkcji filmów brali udział tacy artyści jak m.in. Dymitr Szostakowicz, Sergiej Prokofiew czy Salvador Dali. Przykładem obecności sztuki w kinie jest produkcja „Twój Vincent” Doroty Kobieli i Hugh Welchmana, którzy zaprezentowali wydarzenia z życia malarza poprzez zaanimowanie jego dzieł (Twój..., 2017).

Co istotne, media mogą nie tylko informować, ale także manipulować przekazywanymi treściami, co określa się jako metafory mediacji mediów. Wśród wskazanych przez Denisa McQuaila znajdują się: okno, zwierciadło, filtr, drogowskaz, forum lub scena oraz ekran lub bariera (McQuail, 1994 za: Goban-Klas, 2004, s. 116-117). Pierwsza z wymie- 
nionych metafor tj. okno podkreśla znaczenie ukazywania przez media wydarzeń i przeżyć innych ludzi, bez konieczności kontaktu z innymi. Dlatego też odbiorcy mają możliwość zapoznania się z informacjami nt. ważnych wydarzeń historycznych czy znaczących dla nich osób. Jako przykład można wskazać filmy dokumentalne, które mają na celu zaprezentowanie wiernego obrazu świata. Natomiast, według drugiej z metafor, tj. zwierciadła, które także prezentuje rzeczywistość, w możliwie wierny sposób, zakłada się jednak możliwość wystąpienia zniekształceń. Tym, co różni je od „okna”, jest pewne ograniczenie w postaci perspektywy ukazywania wydarzeń. Przykład mogą stanowić produkcje fabularne oparte na prawdziwych wydarzeniach, które ukazują je z perspektywy prezentowanych osób. Media stanowią także filtr, gdyż przekazują wyselekcjonowane informacje. Tym samym wybierają te, które chcą wyeksponować, a pomijają te mniej znaczące dla nadawcy. Należy podkreślić, że w przekazach, także filmowych nie jest możliwym ukazanie pełnego obrazu rzeczywistości, stąd do nadawcy tych przekazów należy rola wyboru prezentowanych treści. Mediacja przybiera także formę drogowskazu. Dlatego kino także może wyjaśniać prezentowane wydarzenia i zjawiska.

Kolejną z metafor stanowią forum lub scena, na których ukazywane są różne informacje i idee. Denis McQuail wskazuje także na umożliwianie stworzenia publicznej debaty wśród odbiorców. Natomiast ostatnią, z wymienionych przez autora jest metafora ekranu lub bariery. Wskazuje ona na możliwości mediów do przedstawiania fałszywego obrazu świata, co może przybrać dwie formy, tj. rozrywki lub propagandy (za: Goban-Klas, 2004, s. 116-117). Tym samym wskazuje się na zagrożenia płynące z tak przekazywanych treści. Mogą one prowadzić do manipulacji odbiorcami, chcąc wywołać postawy zgodne z oczekiwaniami nadawcy, np. zmiana sposobu myślenia czy zachowania. Wykorzystywanie mediów do celów propagandowych miało miejsce w reżimach totalitarnych, np. w III Rzeszy oraz Związku Radzieckim.

Ponadto, w historii kina można wskazać dwa zjawiska, które w szczególny sposób wpisują się w problematykę narodowo-rasową i mają istotne znaczenie w kontekście sposobu ukazywania mniejszości oraz sposobu przyznawania ról filmowych. Pierwsze z nich stanowi blackface minstrels. Wiązało się ono z charakteryzacją aktorów o „białym” kolorze skóry na Afroamerykanów, przy czym opierało się ono na stereotypowym ujmowaniu tej mniejszości. Tym samym oprócz malowania skóry, przede wszystkim twarzy na kolor czarny, w szczególny sposób podkreślano usta, optycznie je powiększając (Power, 2019, s. 78). Jeden z przykładów, 
w którym można odnotować blackface minstrels stanowi nagrodzony Nagrodą Amerykańskiej Akademii Filmowej „Śpiewak z Jazzbandu”. Inną odmianą tego zjawiska jest yellowface. Dotyczy charakteryzacji mającej na celu upodobnienie do przedstawicieli państw azjatyckich (Lowrey, 2010). Jako przykład można wskazać produkcję „Śniadanie u Tiffany'ego" (Śniadanie..., 1961). Natomiast drugim z ujętych w kinematografii zjawisk jest whitewashing. Podobnie jak blackface minstrels także i ono dotyczy aktorów o „białym” kolorze skóry. Należy jednak zaznaczyć, że w tym przypadku nie wiąże się to ze sposobem charakteryzacji. Tym samym w role postaci należących do innego kręgu kulturowego, o czym świadczy m.in. miejsce akcji wcielają się osoby „białe” (Lowrey, 2010). W historii kina można wskazać wiele przykładów tego zjawiska, także wśród produkcji wyróżnionych Nagrodą Amerykańskiej Akademii Filmowej, co zostało odnotowane w wynikach przeprowadzonego badania.

\section{Metodologia badania}

W badaniu wykorzystano ilościową i jakościową analizę zawartości przekazów filmowych, a próbę badawczą stanowiły wyróżnione Nagrodą Amerykańskiej Akademii Filmowej produkcje w kategorii „najlepszy film”. Pierwsza ceremonia wręczenia „Oscarów” odbyła się w roku 1928, tym samym w bieżącym, 2020 roku miała miejsce jej 92. edycja. Jednakże, ze względu na powstałe w trakcie przeprowadzania analizy ograniczenia w dotarciu do siedmiu filmów w ramach legalnie dostępnych źródeł ostatecznie przebadano 85 produkcji. Wśród nich nie znalazły się takie filmy jak „Cimarron” (1930/31), „Kawalkada” (1932/33), „Król kobiet” (1936), „Życie Emila Zoli” (1937), „Dżentelmeńska umowa” (1947), „Gubernator” (1949) oraz „Marty” (1955)³. Badania ilościowe wymagały utworzenia klucza kategoryzacyjnego, który miał dostarczyć informacji dotyczących m.in. koloru skóry, narodowości, roli, profesji, wieku, usytuowania rodzinnego, charakteru oraz otoczenia analizowanych postaci, tzn. bohaterów o innym kolorze skóry niż „biały” oraz o innej narodowości niż amerykańska. W przypadku gdy jeden

${ }^{3}$ Daty podane w nawiasach są zgodne z publikowanymi na oficjalnej stronie internetowej Amerykańskiej Akademii Filmowej i oznaczają rok, za który zostały wyróżnione.

Lista produkcji wyróżnionych Nagrodą Amerykańskiej Akademii Filmowej w kategorii „najlepszy film”. http://awardsdatabase.oscars.org/search/results, 26.07.2020. 
z bohaterów był reprezentantem obu tych cech kodowany był dwukrotnie. Należy podkreślić, że analizie poddano jedną, najbardziej istotną z perspektywy prezentowanej fabuły osobę ujętą w filmie. Tym samym uwzględniono jej rolę we wskazanej produkcji, tj. bohater pierwszoplanowy, drugoplanowy, czy epizodyczny, jak również ważny aspekt stanowiła znajomość imienia i nazwiska postaci oraz ilość poświęconego jej czasu. Należy zaznaczyć, iż w sytuacji, gdy przedstawicieli prezentowanej mniejszości narodowo-rasowej ujęto jako grupę, wówczas analizowano cechy postaci jako grupy.

\section{Wyniki}

\section{Obecność przedstawicieli mniejszości rasowych, narodowych i etnicz- nych w analizowanych produkcjach filmowych}

W analizowanych 85 produkcjach, w $88,9 \%$ w postać pierwszoplanową wcieliła się osoba o „białym” kolorze skóry. Także wśród przeciwników głównego bohatera, określanych jako „czarny charakter” tylko $12 \%$ stanowiły osoby o innym kolorze skóry. Co istotne, ani razu w tych rolach nie pojawili się przedstawiciele koloru skóry „czerwonego”, ani „brunatnego”. Postać o innym kolorze skóry niż „biała” pojawiła się w 64 produkcjach, przy czym $66 \%$ stanowiły osoby czarnoskóre. Należy podkreślić, że te osoby w ponad połowie produkcji wystąpiły w roli epizodycznej (34), 20 razy w drugoplanowej, natomiast w głównej jedynie 10 razy.

Należy zauważyć, iż przez pierwsze trzy dekady wręczenia Nagrody Amerykańskiej Akademii Filmowej nie pojawił się ani jeden taki bohater w roli pierwszoplanowej. Dopiero w roku 1967 w filmie „W upalną noc" wystąpiła osoba czarnoskóra. Najwięcej takich postaci można zaobserwować w latach 2008-2019, gdyż wówczas aż pięciu bohaterów pierwszoplanowych ma inny kolor skóry niż „biała”, co stanowi najwięcej w całej historii przyznawania tego wyróżnienia.

Inaczej wygląda sytuacja postaci o innej narodowości niż amerykańska, gdyż już w trzeciej edycji został nagrodzony film, w którym główna postać jest Niemcem. W tym przypadku najwięcej, bo aż osiem postaci pierwszoplanowych odnotowano w latach 1958-1967. Postać o innej narodowości niż amerykańska pojawiła się w 69 przykładach. Najczęściej pojawiali się Brytyjczycy, gdyż tej narodowości był co czwarty odnoto- 
Przemiany narodowo-rasowe w kulturze popularnej na przykładzie kina...

wany bohater. Na drugim miejscu (14\%) wskazano Włochów, natomiast na trzecim $(9 \%)$ Niemców. W przypadku narodowości i roli bohatera w filmie sytuacja wygląda inaczej niż to miało miejsce w stosunku do osób o innym kolorze skóry niż „biała”. Tym samym jako postać epizodyczna pojawili się oni 17 razy, drugoplanowa - 15 razy, natomiast jako pierwszoplanowa - w 37 produkcjach, co stanowi ponad połowę filmów $\mathrm{z}$ ich udziałem.

\section{Blackface minstrels $i$ whitewashing $w$ analizowanych produkcjach}

W badanych produkcjach pojawiły się zjawiska, które zostały wcześniej omówione. Whitewashing miał miejsce w takich przykładach jak np. „West Side Story” (1961), „W 80 dni dookoła świata” (1956), czy „Ben Hur” (1959). W pierwszym dotyczy on postaci głównej bohaterki Portorykanki, w której rolę wcieliła się amerykańska aktorka Natalie Wood (Natalie...). W drugim z wymienionych filmów hinduską księżniczkę zagrała Shirley MacLaine, również Amerykanka (Shirley...). Natomiast w ostatnim, w tytułową postać, narodowości żydowskiej wcielił się, także pochodzący ze Stanów Zjednoczonych Charlton Heston (Charlton...). Innym zjawiskiem, które również wystąpiło w analizowanych przykładach stanowi blackface minstrels. Zostało ono odnotowane w czterech produkcjach, tj. „Amadeuszu” (1984), „Ostatnim cesarzu” (1987), „Ben Hurze” (1959) oraz „W upalną noc” (1967). W dwóch pierwszych taka sytuacja miała miejsce podczas przyjęć, w których uczestniczyli główni bohaterowie, tj. służący oraz muzyk zostali ucharakteryzowani w ten sposób. W trzecim była to postać szejka, w którego roli wystąpił brytyjski aktor o „białym” kolorze skóry Hugh Griffith (Hugh...). Szczególny przykład stanowiła ostatnia z wymienionych produkcji, gdyż tam zjawisko to zostało uchwycone nie w przypadku jednego $\mathrm{z}$ bohaterów, a figurki, którą ustawiono przed domem postaci znanej ze swoich rasistowskich poglądów.

\section{Obraz niewolnictwa $i$ segregacji rasowej $w$ analizowanych przyktadach}

Oprócz wspomnianych zjawisk, w produkcjach odnotowano również systemy silnie związane z dyskryminacją na tle rasowym, w postaci niewolnictwa i segregacji, które obowiązywały w Stanach Zjednoczonych Ameryki. Pierwszy z nich zakończyła XIII Poprawka do Konstytucji 
z 1865 roku (Weisberger, 1995, s. 55), natomiast drugi - ustawy z lat 1964-1965 (Graham, 1995, s. 94). Niewolnictwo zostało ukazane w kilku z analizowanych produkcji, jednak w szczególny sposób zostało ono ujęte w „Przeminęło z wiatrem” (1939) i „Zniewolonym. 12 years of Slave” (2013). W obu zaprezentowano dwie różne perspektywy spojrzenia na ten system, co wynikało z okresu, w którym powstały. Należy jednak zaznaczyć, iż czas i miejsce, w którym rozgrywa się ich fabuła jest zbliżony tj. II połowa XIX wieku w stanach południowych. W pierwszym przykładzie niewolnictwo stanowiło powszechny i naturalny system, którego zmiana budziła niechęć nawet wśród osób o „czarnym” kolorze skóry. W sytuacji, kiedy ktoś podzielał odmienne stanowisko, zwłaszcza po zakończeniu Wojny Secesyjnej był odbierany wrogo przez głównych bohaterów. W drugim z przykładów została przedstawiona tragiczna historia tytułowej postaci o „czarnym” kolorze skóry, którą „zniewolono”. Bohater jako „wolny człowiek" został porwany i wywieziony na Południe w roli niewolnika. Tym samym nie był już postrzegany jako człowiek, a czyjaś własność.

Mimo zniesienia tego systemu został on zastąpiony przez segregację rasową, którą także ukazano $\mathrm{w}$ wielu $\mathrm{z}$ nagrodzonych produkcji. Miało to miejsce w m.in. „Gandhim” (1982), „W upalną noc” (1967), czy „Green Booku” (2018). W pierwszym z wymienionych tytułowy bohater sam jej doświadcza już w jednej z pierwszych scen produkcji, kiedy ze względu na swoje pochodzenie nie może kontynuować podróży pociągiem w pierwszej klasie, mimo posiadanego biletu. Dotyczy to także kwestii obowiązku noszenia przez Hindusów odpowiednich przepustek, zakazu chodzenia po chodniku, czy pracy jedynie w dedykowanych dla nich miejscach np. kopalniach. W kolejnym z wymienionych następuje zestawienie zasad obowiązujących w latach 60. na północy i na południu Stanów Zjednoczonych. Poruszona zostaje kwestia ubioru, profesji, ale także odmowy obsługi w restauracji czy niesłuszne oskarżenie głównego bohatera o morderstwo, spowodowane wyłącznie tym, że ma „czarny” kolor skóry. Także „Green Book” porusza kwestie segregacji rasowej, której doświadcza postać czarnoskóra. Mimo statusu gwiazdy, gdyż jest cenionym pianistą, podczas tournée na południu kraju także dotykają go skutki tego systemu. Wiążą się z tym wynajęcie pokoju na nocleg, gdyż nie ze wszystkich, mimo swojej pozycji może skorzystać, odmawia się mu obsługi w sklepie czy w miejscu koncertu nie może skorzystać z toalety w budynku oraz zjeść w znajdującej się tam restauracji. 
Przemiany narodowo-rasowe w kulturze popularnej na przykładzie kina...

\section{Znaczenie przemian spoleczno-kulturowych dla kinematografii amerykańskiej}

W 92-letnim okresie przyznawania Nagród Amerykańskiej Akademii Filmowej można odnotować momenty przełomowe w zakresie przemian narodowo-rasowych. Za pierwszy z nich można uznać wyróżnienie statuetką produkcji „W upalną noc” w 1967 roku. Jest to pierwszy nagrodzony „Oscarem” film, w którym postać pierwszoplanowa ma inny kolor skóry niż „biała”. W fabule poruszono problematykę konfliktów na tle rasowym, a także wskazano różnice między stanami północnymi a południowymi. Jak już wspomniano wcześniej, w latach 1964-1965 w wyniku zmian w prawie amerykańskim zniesiono segregację rasową. Kolejny moment, o którym należy wspomnieć stanowił atak terrorystyczny na World Trade Center w Nowym Jorku 11 września 2001 roku, co zapoczątkowało wojnę między Irakiem a Stanami Zjednoczonymi. Tym samym ponownie $\mathrm{w}$ przestrzeni publicznej pojawiła się kwestia różnic narodowo-rasowych i wynikających z nich konfliktów, co znalazło swoje odzwierciedlenie także w kinematografii. Dlatego też twórcy podejmowali w swoich produkcjach zarówno tematykę wojenną związaną z aktualnymi wydarzeniami (np. „The Hurt Locker. W pułapce wojny”), ale także odwoływali się do historii Stanów Zjednoczonych i wynikających z niej współczesnego izolacjonizmu i rasizmu (Smith, 2019, s. 544-545). Wyrazem ostatniego z wymienionych aspektów może być „Miasto gniewu” z 2004 roku (Miasto..., 2004). Produkcja także została wyróżniona przez Amerykańską Akademię Filmową. Jej fabuła oparta jest na uprzedzeniach, stereotypach, czy nieporozumieniach powstałych w wyniku wspomnianych różnic, nawiązując także do konfliktu między Stanami Zjednoczonymi a Irakiem. Pokazuje, że mimo zmian legislacyjnych, podziały wciąż istnieją w społeczeństwie amerykańskim, a dysproporcje coraz częściej są zauważane i podkreślane przez twórców.

Należy podkreślić, że nie tylko wśród przedstawicieli środowiska filmowego, ale także osób powszechnie znanych i samych odbiorców zaczęto zwracać uwagę na dyskryminację na tle narodowo-rasowym związaną z przyznawaniem wspomnianej nagrody. Szczególnie stało się to widoczne w 2015 roku, kiedy wśród nominacji do „Oscarów” Akademia wskazała wyłącznie osoby o „białym” kolorze skóry. Skutkiem tego użytkownicy jednego z portali społecznościowych zapoczątkowali oznaczenie „\#OscarsSoWhite”, wyrażającego sprzeciw wobec polityki wspomnianej instytucji (Grossman, 2015). W kolejnych latach, gdy mia- 
ła miejsce podobna sytuacja, tj. odbiorcy odnotowali dysproporcje wśród nominowanych na tle rasowym i także reagowali w podobny sposób. Niektórzy z twórców jak np. Spike Lee czy Will Smith zrezygnowali wówczas z udziału w wydarzeniu (Ryan, 2016).

Dlatego też w ostatnich latach można odnotować zmianę w kontekście przyznawania ról pierwszoplanowych aktorom o innym kolorze skóry niż „biały”, co wiąże się z poruszaną we wspomnianych wcześniej produkcjach problematyką narodowo-rasową. Stąd też od 2015 roku nagrodzono dwa filmy, których fabuła porusza wspomniane wątki tj. „Moonlight”, czy „Green Book”. Należy także zaznaczyć, że tegoroczny laureat Nagrody Amerykańskiej Akademii Filmowej, koreański „Parasite” stanowi pierwszy w historii film nieanglojęzyczny, który zdobył statuetkę w kategorii ,najlepszy film”.

\section{Zakończenie}

Przemiany na tle narodowo-rasowym można zauważyć w przekazach filmowych, co wykazała przeprowadzana analiza. Dotyczy to zarówno podejmowanych przez twórców tematów, zwłaszcza w nagrodzonych w ostatnich latach produkcjach, jak również udziału przedstawicieli mniejszości i wcielanie się nich w role pierwszoplanowe. Należy zaznaczyć, że sformułowana na potrzeby analizy hipoteza badawcza potwierdziła się. Tym samym wydarzenia historyczne o znaczeniu narodowo-rasowym w Stanach Zjednoczonych mają wpływ na przemiany zachodzące $\mathrm{w}$ przemyśle filmowym w postaci m.in. polityki obsadzania ról. Szczególnym tego wyrazem jest wspomniany wcześniej film pt. „W upalną noc".

Zmiany można także zaobserwować w reakcji osób powszechnie znanych oraz odbiorców, którzy sprzeciwiają się dyskryminacji na tym tle. Szczególny tego wyraz można było zauważyć po ogłoszeniu nominacji do Nagrody Amerykańskiej Akademii Filmowej w 2015 roku, w wyniku czego nastąpiła popularyzacja oznaczenia „OscarsSoWhite” w mediach społecznościowych. Dlatego też debata publiczna podnosząca znaczenie tej problematyki mogła mieć znaczenie w kontekście podejmowania w produkcjach wątków narodowo-rasowych i ich nagradzania w latach 2017, 2019 i 2020. Jest to szczególnie istotne, ze względu na rolę, jaką pełnią media, w tym także kino. To one poprzez pośredniczenie między twórcami, a widzami prezentują określony obraz rzeczywistości i wskazu- 
Przemiany narodowo-rasowe w kulturze popularnej na przykładzie kina...

ją sposób interpretacji ukazywanych zjawisk. Tym samym, gdy następuje usprawiedliwienie lub potępianie działań mających na celu dyskryminację, może to wpływać na postawy odbiorców. Należy jednak podkreślić, że wśród wyróżnionych produkcji, nadal ok. $89 \%$ ról pierwszoplanowych została przyznana aktorom o „białym” kolorze skóry. Podkreśla to znaczenie podnoszonych kwestii na tle narodowo-rasowych w przestrzeni publicznej i oznacza, że proces wyrównywania szans w tym zakresie dopiero się rozpoczął, a równouprawnienie najprawdopodobniej nastąpi dopiero w przyszłości, do czego mogą się przyczynić zmiany wprowadzone przez Amerykańską Akademię Filmową.

\section{Bibliografia}

Adamczyk W. (2005), Kino uczy, wychowuje, uwodzi, https://www.kulturaihistoria. umcs.lublin.pl/archives/61?fbclid=IwAR3JOVJ31XTYh0MwNAewmo bH9AKK_DkiiWCCO8rTsHnLW2J4orWJKZB5bU, 25.01.2020.

Altman R. (2012), Gatunki filmowe, Warszawa.

Aronson E., Wilson T. D., Akert R. M. (1997), Psychologia społeczna, Poznań.

Baldwin E. i in. (2007), Wstęp do kulturoznawstwa, Poznań 2007.

Goban-Klas T. (2004), Media i komunikowanie masowe. Teorie i analizy prasy, radia, telewizji i Internetu, Warszawa.

Graham H. D. (1995), Era Kennedy'ego - Johnsona, w: Historia Stanów Zjednoczonych Ameryki, t. 5: 1945-1990, red. D. T. Critchlow, K. Michałek, Warszawa.

Grossman S. (2015), Almost All the Oscars Nominees Are White, https://time. com/3669143/oscars-2015-nominations-white/, 16.04.2020.

Hendrykowski M. (1988), Historia filmowego Oscara, Warszawa.

Jasińska-Kania A., Skarżyńska K. (2001), Stereotypy narodowe i nacjonalizm w perspektywie międzynarodowych badań porównawczych, w: Stereotypy $i$ uprzedzenia. Uwarunkowania psychologiczne i kulturowe, red. M. Kofta, A. Jasińska-Kania, Warszawa.

Jenkins P. (2009), Historia Stanów Zjednoczonych, Kraków.

Jimenez O., Chavez N., Hanna J. (2020), As heated protests over George Floyd's death continue, Minnesota governor warns of 'extremely dangerous situation', https://edition.cnn.com/2020/05/27/us/minneapolis-protests-georgefloyd/index.html, 27.09.2020.

Kossecki J. (2015), Naukowe podstawy nacjokratyzmu, Warszawa.

Krajewski M. (2005), Kultury kultury popularnej, Poznań.

Lowrey W. (2010), People Painted Over: Whitewashing of Minority. Actors in Recent Film, https://www.palmbeachstate.edu/honors/Documents/People_Painted 
Over_Whitewashing_of_Minority_Actors_in_Recent_Film-_and\%20_Television.pdf, 8.04.2020.

Pancewicz M. (2011), Mniejszości w filmowych produkcjach Hollywood. Reprodukcja podziałów społecznych $i$ stereotypów, http://cyfrowaetnografia.pl/Content/4747/Mniejszości\%20w\%20filmowych\%20produkcjach \%20Hollywood.pdf, 8.04.2020.

Piątek J. (2006), Zdjąć z ekranów „Kod Leonarda da Vinci”?, http://www.kosciol.pl/ article.php?story=20060518 193943716, 24.01.2020.

Płażewski J. (2007), Historia filmu, Warszawa.

Power D. (2019), Początki kina dźwiękowego, w: Historia kina, red. P. Kemp, Warszawa.

Rode D. (2014), Aktywistyczne użycia (nowych) mediów: wybrane działania $w$ polskim ruchu feministycznym, w: Film i media-przeszłość i przyszłość. Kontynuacje, red. A. Gwóźdź, M. Kępna-Pieniążek, Warszawa.

Ryan P. (2016), \#OscarsSoWhite controversy: What you need to know, https:// eu.usatoday.com/story/life/movies/2016/02/02/oscars-academy-award-nominationsdiversity/79645542/, 29.09.2020.

Smith I. H. (2019), Amerykański dramat po 11. września, w: Historia kina, red. P. Kemp, Warszawa.

Smith S. L., Choueiti M., Pieper K. (2013), Race/Ethnicity in 600 Popular Films: Examining On Screen Portrayals and Behind the Camera Diversity, https:// annenberg.usc.edu/sites/default/files/MDSCI_Race_Ethnicity_in_600_Popular_Fims.pdf, 14.04.2020.

Weisberger B. A. (1995), Wojna secesyjna 1861-1865, w: Historia Stanów Zjednoczonych Ameryki, t. 3: 1848-1917, red. W. Nugent, H. Parafianowicz, Warszawa.

Weisberger B. A. (1995), Rekonstrukcja 1865-1877, w: Historia Stanów Zjednoczonych Ameryki, t. 3: 1848-1917, red. W. Nugent, H. Parafianowicz, Warszawa.

Wojciszke B. (2017), Psychologia społeczna, Warszawa.

Wojtaszak A. (2015), Nacjonalizm. Ewolucja myśli politycznej. Zarys problemu, „Zeszyty Naukowe Uniwersytetu Szczecińskiego. Acta Politica”, nr 32, Szczecin.

Black Live Matter, About, (2020), https://blacklivesmatter.com/about/, 27.09.2020.

Charlton Heston, https:/www.imdb.com/name/nm0000032/, 9.07.2020.

Gwiezdne wojny: Skywalker. Odrodzenie (2019), https://www.imdb.com/title/ tt2527338/, 24.01.2020.

Hugh Griffith, https://www.imdb.com/name/nm0341518/, 9.07.2020.

Miasto gniewu (2004), https://www.imdb.com/title/tt0375679/, 4.06.2020.

Natalie Wood, https://www.imdb.com/name/nm0000081/, 9.07.2020.

Oscars (2020), Academy Establishes Representation And Inclusion Standards For Oscars ${ }^{\circledR}$ Eligibility, https://www.oscars.org/news/academy-establishes-representation-and-inclusion-standards-oscarsr-eligibility, 28.09.2020. 
Przemiany narodowo-rasowe w kulturze popularnej na przykładzie kina...

Shirley MacLaine, https://www.imdb.com/name/nm0000511/, 9.07.2020.

Śniadanie u Tiffany'ego (1961), https://www.imdb.com/title/tt0054698/, 9.07.2020.

The Official Academy Awards ${ }^{\circledR}$ Database. Results (2020), http://awardsdatabase.oscars.org/search/results, 26.07.2020.

Wonder Woman (2017), https://www.imdb.com/title/tt0451279/, 24.01.2020.

The Academy (2020), https://www.instagram.com/p/CE5U-hwsk-U/, 28.09.2020.

Twój Vincent (2017), https://www.imdb.com/title/tt3262342/, 1.08.2020.

\section{National and racial changes in popular culture on example of American cinema}

\section{Summary}

The racial segregation was abolished in american law in 1960s, however its effects in public space are visible nowadays. It is about stereotypes and discrimination against national and racial minorities. It is present in cinematography among others by disproportion of allocation of film roles, way of showing characters and also by occurence like whitewashing or blackface minstrels. The purpose of this article is to show the changes, which took place in the last century. The research trial were 85 productions awarded American Academy Award in category "Best Picture". The conducted analysis showed that in the history of American cinema, breakthrough moments in the field of national and racial transformations can be identified and the above-mentioned phenomena were included.

Key words: United States of America, cinema, race, nationality, culture

\section{Informacja 0 autorze}

Daria Zadrożniak (daria.zadrozniak@amu.edu.pl) - absolwentka dziennikarstwa i komunikacji społecznej, obecnie doktorantka w Szkole Doktorskiej Uniwersytetu im. Adama Mickiewicza w Poznaniu. 
- 